UDC 351.741(477)

Kryvolapchyk Volodymyr, Doctor of Juridical Sciences, Professor, Director of the State Research Institute MIA Ukraine,

Kyiv, Ukraine,

ORCID ID 0000-0001-9449-2242

\title{
PREVENTIVE ACTIVITIES OF THE NATIONAL POLICE OF UKRAINE IN THE CURRENT LEGAL SPHERE
}

The article investigates the essence and content of legal regulation of the National Police of Ukraine in the direction of prevention. The legal nature of preventive police measures, their practical use and application by the police in order to the prevention, preclusion and suppression offences, their role in ensuring public safety and order in the state, as well as crime counteraction are considered. The author's definitions of the subject matter and concepts of "legal regulation", "preventive policing" and "preventive police accounting" are set out. On the basis of the research it was proposed to introduce amendments and additions to the current legislation of Ukraine.

Keyzords: prevention, legal regulation, preventive policing, preventive police accounting, preclusion, offences.

The main feature of the rule of law is the effective legal regulation of social ties. Therefore, interaction with the National Police of Ukraine should be based on the definition of the areas of activity of its bodies, structural subdivisions and officials that ensure the daily democratic regime of these relations on the basis of the rule of law, inviolability of constitutional rights and freedoms of a human being and citizen.

The effectiveness of the preventive police measures of the National Police depends on the improvement of the normative regulation of police activity, the clarity of legal regulations, the existence of a developed system of legislation and relevant bylaws in this area.

O.F. Andriiko, O.M. Bandurka, V.I. Varenka, I.P. Holosnichenko, Ye.V. Dodina, R.A. Kaliuzhnyi, A.P. Kliushnichenko, A.M. Kolodii, A.T. Komzuk, V.V. Kopieichykova, M.V. Koval, A.T. Komziuk, M.V. Korniienko, S.L. Lysenkova, O.V. Nehotchenko, S.V. Petkov, P.M. Rabinovich, Yu.I. Rymarenko, O.F. Skakun, O.D. Tikhomirova, I.M. Shopina, Yu.S. Shemshuchenko V.K. Shkarupa, dedicate their writings to the issues of organization of legal regulation of activities in the state, society, including the bodies of internal affairs and police. Determination of the nature and peculiarities of preventive and coercive police measures carried out by the police was studied by D.M. Bakhrach, Ye.A. Bessmertnyi, H.P. Bondarenko, I.O. Galagan, V.K. Kolpakov, O.P. Korenev, O.M. Lunov, O.P. Sherhin, O.M. Yakuba and other scientists in the field of administrative law. However, the administrative and legal aspects of preventive police measures, despite their theoretical and practical significance and importance, remain undisclosed or debatable. 
The purpose of the article is the analysis of administrative and legal aspects of legal regulation of the National Police of Ukraine in the field of prevention, preventive police measures and preventive police accounting.

Scientific literature has consistently noted the place of law and legal regulation in the organization of any activity of the state and society. In this regard, A.F. Skakun understands legal regulation as the regulation of social relations, their legal consolidation, protection and development, carried out with the help of law and a set of legal means [1,704 p.]. A.T. Kozmyuk notes that legal regulation is a specific impact, which is carried out by law as a special normative institutional regulator. The peculiarity of legal regulation is such a type of social regulation, which has a purposeful, structured, effective character and is carried out through a targeted system of means that realistically reflects the very essence of law as a normative institutional formation - a regulator [2, 408 p.].

Thus, legal regulation is defined as the action of the right to public relations with the help of certain legal means, first of all the norms of law [3, 320 p.]. A.N. Bandurka groundedly notes: "Legal regulation ensures distribution of control and supervision powers between different bodies and services, officials, establishing certain relations between them" [4, 780 p.]. K.F. Skvortsova specifies: "Legal regulation in any spheres of state activity concerns not only the definition of rights and obligations of subjects of legal relations, but also the construction of this system and, finally, the main issues of the organization of the activities of its individual parts" [5, 160 p.]. With such principles in mind, it should be noted that one of the initial stages of legal regulation is the legal norms that constitute the regulatory framework, the core of the legal regulation mechanism.

Having described the definitions of legal regulation, we determine that the concept of legal regulation should be understood as the ordering of social relations, carried out by the state with the help of law and a set of legal means, their legal fixation, protection and development.

The aggregate of methods and receptions, owing to which social relations of a certain type regulated, are methods of legal regulation.

There are three traditional methods of legal regulation: authorization, obligation and prohibition. Consequently, the specified methods of legal regulation correspond to the direct forms of implementation of legal norms: use, execution, compliance.

At the same time, the legal regulation of police activity in Ukraine provides:

Firstly, considering that legal norms are both a means and the main instrument of management of social objects, and at the same time a regulator of police activity, and a set of social norms and procedures of their implementation, which ensure normal functioning and development of systems in accordance with the conditions of their existence. The State, with the help of legal norms, confers certain powers (duties and specific rights) on State authorities and their officials (subjects of police activity), within the limits of powers and in the ways provided for by the Constitution and the laws of Ukraine.

Secondly, the provision of the legislative, executive and judicial branches of government, the Public Prosecutor's Office and in particular the National Police, as one of the enforcement authority. At the same time, the current legislative and

DOI (Article): https://doi.org/10.36486/np.2019.2.07

(C) Kryvolapchuk Volodymyr, 2019 
regulatory regulation of police activity in Ukraine, including the bodies of the National Police, plays an important role, since the effectiveness of legal regulation depends largely on the improvement of its legal framework, clarity of instructions, and the existence of a developed system of legal norms. Legal norms are used to ensure: defining a system of police powers to ensure the implementation of preventive police measures by the police authorities and units; the distribution of functions between the units of a given police authority and their employees for the implementation of preventive police measures; and the consolidation of the system of facilities and objects of police activity of the National Police.

Thirdly, the clarification of the number of public relations that arise, that is to say, the definition of the subject of legal regulation, which covers all public relations, which objectively by their nature can succumb to regulatory and organizational impact and in these socio-political conditions require such an impact, carried out with the help of legal norms and all other legal means.

Fourth, it makes it possible to determine the role of law in the regulation of police activity in Ukraine, carried out with the help of legal norms, which are legally enshrined in: 1) the system of police officers' powers to realize their rights; 2) forms, types, directions and permissible limits of police activity in the implementation of preventive police measures; 3 ) the system of objects and subjects of law enforcement activity of police officers; 4) distribution of supervisory functions between subdivisions of a certain body and their employees; 5) basic parameters of interaction and coordination of the activities of the subjects of police activity in the implementation of preventive police measures; 6) legal protection of the interests of the subjects of police cooperation; 7) the system of preventive police measures in the interests of ensuring the rule of law, protection of human and civil rights and freedoms, interests of society and the state, as well as stability of public relations.

So far, the bodies of the National Police of Ukraine operate within a certain territory and, accordingly, are reporting and under the control of the executive authorities, primarily the Cabinet of Ministers of Ukraine. The bodies of the National Police of Ukraine, as subjects of police activity, differ in a number of ways. First and foremost, these are the bodies that carry out control and supervision functions; they continuously perform special state powers in relation to the subjects subordinated to them, which are obliged to implement the decisions taken by the bodies of the National Police of Ukraine, within their competence. Thus, we are talking about powers above departmental ones. It is necessary to understand that this body is vertically interconnected, in particular, there are internal subordination relations, as well as control functions in relation to its activities, vested with authoritative powers.

Current police activity in Ukraine is characterized by the following signs:

- is based on the Basic Law and the laws of Ukraine;

- is aimed at objects, the composition of which depends on a specific stage of historical development of the society and political factors;

- Its content in our society is organically connected with law and legal understanding, and it clearly expresses the inextricable link between the state and law, their mutual influence;

- is a public policy; 
- is formed and implemented under the influence of a complex of objective and subjective factors (legal consciousness of a person, citizen and society as a whole, the state of crime, economic development of the state, personnel policy selection and placement), political leadership of the state, its attitude to this issue;

- is implemented through managerial, organizational and legal means and through the use of preventive police measures, as well as the use of State coercive police measures, etc.

At the same time, legal regulation of police activity in Ukraine is contained in legislative and regulatory acts of various forms, nature and legal force.

As a form of existence, legal norms are designed to regulate relations in the area of policing in the direction of prevention, and regulatory instruments are a way of fixation and their action, their place of stay in the social and legal dimension of the national legal system. Through normative and legal acts, the content of legal norms, provisions of law enforcement practice, as well as in most cases individual prescriptions and decisions of individual officials are disclosed.

For instance, according to Article 3 of the Law of Ukraine "On the National Police" dd. 02.07.2015 No. 580-VIII, it is stated that in its activities the police are guided by the Constitution of Ukraine, international treaties of Ukraine, consent to be bound by the Verkhovna Rada of Ukraine, the indicated Law and other laws of Ukraine, acts of the President of Ukraine and resolutions of the Verkhovna Rada of Ukraine adopted in accordance with the Constitution and laws of Ukraine, acts of the Cabinet of Ministers of Ukraine, as well as acts of the Ministry of Internal Affairs of Ukraine issued in accordance with it, and other normative and legal acts [6, 379 p.].

Thus, the legal regulation of the activity of the National Police of Ukraine in the area of prevention is provided by a specially created state mechanism, the main component of which is the existing rules of law laying down in laws and other legal acts, regulated by a significant number of regulatory acts, which differ from each other in many ways: the name, legal force, the order of adoption, entry into force, etc.

Thereby, the legislation of Ukraine in the sphere of legal regulation of the activity of the National Police of Ukraine in the area of prevention is premised on the Basic Law of Ukraine and represents a set of laws, which implement the legal impact of the state on public affairs with the help of legal norms. All legal norms are equally aimed at the ultimate goal, but their content, procedure of establishment and influence on the processes of legal regulation of police activity in the sphere of action and the mechanism of distribution in the legal system are different. The State confers certain powers (duties and specific rights) on the National Police and its officers (subjects of policing), within which they carry out police activities and are guided by the laws of Ukraine, international treaties of Ukraine, the consent to be bound by which is given by the Verkhovna Rada of Ukraine, acts of the President of Ukraine and decisions of the Verkhovna Rada of Ukraine, the legal acts (orders and instructions) of the Ministry of Internal Affairs and the National Police of Ukraine adopted in accordance with the Constitution and the laws of Ukraine, the decisions and instructions of the Cabinet of Ministers of Ukraine, as well as the legal acts (orders and instructions) of the Ministry of Internal Affairs of Ukraine and the National Police of Ukraine issued in accordance with it, and other regulatory and legal acts.

DOI (Article): https://doi.org/10.36486/np.2019.2.07

(C) Kryvolapchuk Volodymyr, 2019 
This being so, the stated gives grounds for the formulation of the concept of "preventive activity" as an activity provided for by the current legislation of Ukraine, aimed at: prevention and is carried out to the formation of illegal intent; prevention and occurs after the formation of illegal intent before the beginning of its implementation and through the commission of an offence, the suppression of offences committed after the beginning of the offence with the possible application of measures to persons, verification of compliance with the requirements established by law, restrictions, as well as with respect to persons on the preventive account. The application of preventive measures by the police complements educational, informational and awareness-raising activities and is based on the principles of legality, necessity, proportionality, effectiveness and respect for human rights and freedoms. Preventive police measures provide for the application of restrictions on certain rights and freedoms in persons and organizations in cases prescribed by law, and this manifests itself as mandatory, although there are no offences against them. That is, these measures have a clear preventive direction, focused on the protection of public safety and order, on the avoidance of offenses. The essence of the prophylactic effect of preventive police measures is, firstly, to avoid unlawful conduct on the part of persons who engage in such conduct, and secondly, to eliminate the causes contributing to the commission of offences and to create conditions precluding unlawful conduct.

In order to ensure the objectives of preventive action, there is a need for preventive police accounting. Such accounting shall be applied to persons who are prone to committing offences and to persons registered with the police to prevention them from committing offences.

The National Police carries out preventive work with persons released from places of deprivation of liberty who have served their sentences for intentional crimes and where the criminal record has not been removed or cancelled in accordance with the procedure established by law, as well as with persons who have been officially warned not to commit domestic violence.

The term "preventive police monitoring" should be understood to mean a series of measures carried out by the unified information system of the Ministry of Internal Affairs of Ukraine, aimed at maintaining proper technical condition of information subsystems on persons on the preventive records and for whom preventive work is carried out by the National Police.

With these matters cleared away, let's summarize that legal regulation is a regulation of social relations carried out by the state with the help of law and a set of legal means, their legal fixation, protection and development. The legal regulation of preventive policing has its own peculiarities. By methods of legal regulation, we understand - a set of methods and techniques by which the community relations of a certain type are ordered.

Relying on the results of the study, we propose to amend Article 30 and Article 31 of the Law of Ukraine No. 580-VIII "On the National Police" dated July 2, 2015 by adding section 2 of Article 30 by paragraph 2 and 3 of the following content:

"Preventive police activity is the activity provided by the current legislation of Ukraine, aimed at prevention, carried out to the formation of illegal intent, avoidance that occurs after formation of illegal intention before the beginning of its realization

DOI (Article): https://doi.org/10.36486/np.2019.2.07

(C) Kryvolapchuk Volodymyr, 2019 
and through commitment of an offence, suppression of the offences made after the beginning of fulfillment of an offence with possible application to persons of measures, check of observance of the requirements established by the law, restrictions, and also concerning persons on the preventive account.

Preventive police accounting is a set of measures implemented by the unified information system of the Ministry of Internal Affairs of Ukraine, which is aimed at maintaining the proper technical condition of the information subsystems of the unified information system of the Ministry of Internal Affairs on persons on the preventive record keeping and for which the National Police are carrying out preventive work".

\section{REFERENCES}

1. Skakun O.F. (2000) Teoriia gosudarstva i prava: uchebnik. "Theory of State and Law": a textbook. Kharkov: Consum. Univ. Intern. Affairs. 704 p. [in Russian].

2. Kozmiuk A.T. (2002) Administratyvnyi prymus v pravookhoronnii diialnosti militsii v Ukraini. "Administrative coercion in law enforcement activities of the police in Ukraine": diss. Ph.D. 12.00.07 Kharkiv. National University of Internal Affairs. Kharkiv. 408 p. [in Ukrainian].

3. Zahalna teoriia derzhavy i prava / za red. V.V. Kopieychykova. "General theory of state and law” / ed. V.V. Kopieichykova Kyiv: Yurinkom, 1997. 320 p. [in Ukrainian].

4. Bandurka O.M. (2004) Teoriia i praktyka upravlinnia orhanamy vnutrishnikh sprav Ukrainy. "Theory and practice of management of internal affairs of Ukraine". Kharkiv. 780 p. [in Ukrainian].

5. Problemy effektivnosti nadzora. "Problems of the effectiveness of supervision" / Ed. K.F. Skvortsova. Moscow: Legal. Lit., 1977. 160 p. [in Russian].

6. Pro Natsionalnu politsiiu. "About the National Police": Act dated July 2, 2015 No. 580VIII. Information from the Verkhovna Rada of Ukraine dated 09.10.2015. $\quad$ No. 40-41. 379 p. [in Ukrainian].

УДК 351.741(477)

Криволапчук Володимир Олексійович, доктор юридичних наук, професор, директор ДНДІ МВС України, м. Київ, Україна, ORCID ID 0000-0001-9449-2242

\section{ПРЕВЕНТИВНА ДІЯЛЬНІСТЬ НАЦІОНАЛЬНОЇ ПОЛІЦІЇ УКРАЇНИ В СУЧАСНОМУ ПРАВОВОМУ ПОЛІ}

У статті досліджено сутність і зміст правового регулювання діяльності Національної поліції України за напрямом превенції, яке забезпечується за допомогою спеціально створеного державного механізму, основним елементом якого є норми права, закріплені в законах та інших правових актах, якими визначається модель поведінки суб'єкта суспільних відносин - органу поліції за напрямом превенції.

Розглянуто правову природу превентивних поліцейських заходів, проаналізовані питання їх практичного використання і застосування Національною поліцією України з метою профілактики, запобігання і припинення правопору-

DOI (Article): https://doi.org/10.36486/np.2019.2.07

(C) Kryvolapchuk Volodymyr, 2019 
шень, визначено їх роль у забезпеченні публічної безпеки і порядку в державі, протидії злочинності.

Викладено авторські визначення предмета й поняття правового регулювання як упорядкування суспільних відносин, здійснюваного державою за допомогою права і сукупності правових засобів та їх юридичного закріплення, а також методів правового регулювання як сукупності способів і прийомів, за допомогою яких упорядковуються суспільні відносини визначеного виду.

Крім того, запропоновано авторське визначення поняття “превентивна поліцейська діяльність” як діяльность, передбачена чинним законодавством України, спрямованої на: профілактику та здійснення до формування протиправного умислу; відвернення, що відбувається після сформування протиправного умислу до початку його реалізації і через вчинення правопорушення; припинення правопорушень, здійснених після початку вчинення правопорушення із можливим застосуванням до осіб запобіжних заходів, перевірки дотримання встановлених законом вимог, обмежень, а також стосовно осіб, які перебувають на превентивному обліку. Сформульовано поняття “превентивний поліцейський облік”, яке запропоновано розглядати як комплекс заходів, здійснюваний єдиною інформаційною системою МВС України для забезпечення ефективної роботи інформаційних підсистем обліку осіб, які перебувають на профілактичних обліках та щодо яких здійснюється превентивна робота органами Національної поліції України.

Зважаючи на викладене вище, запропоновано внести зміни та доповнення до ст.ст. 30 та 31 Закону України від 02.07.2015 № 580-VIII “Про Національну поліцію”.

Ключові слова: превенція, правове регулювання, превентивна поліцейська діяльність, превентивний поліцейський облік, профілактика, запобігання, правопорушення.

Отримано 05.06.2019

DOI (Article): https://doi.org/10.36486/np.2019.2.07 Issue 2(4.4) 2019
(C) Kryvolapchuk Volodymyr, 2019 